\title{
Author's Introduction
}

A book about Jewish soldiers and chaplains in the Habsburg armies is a could complete. Unlike the relatively homogenous German army, the AustroHungarian military was a polyglot of many nationalities and languages. Whereas a knowledge of English, German, and Hebrew had previously sufficed for my purposes, the current project necessitated an additional knowledge (which I do not possess) of Yiddish, Hungarian, Czech, Polish, Serbo-Croatian, Italian, and Russian, and access to books and archives around the world, which was nearly impossible for an amateur working alone, with no funding.

I began with German-speaking Austrians and, even there, pickings were slim compared to those of Germans. Austro-Hungarian Jewish solders seemed less likely to put their thoughts on paper, compared to German counterparts. There are, of course, significant exceptions, such as diaries of Bernhard Bardach and Teofil Reiss, and books by Egon Erwin Kisch, Hans Kohn, Kaspar Blond, Adolf Epstein, Georg Breithaupt, and Lavoslav Kraus, but most of these are either handwritten in Sütterlin, or difficult to obtain. The Epstein and Breithaupt books, for example, are available in only two or three libraries in the world.

Habsburg Jews were admitted into the military before the French Revolution, but unlike French Jews to whom Napoleon gave full equality, Jews under Joseph II did not have equal rights. Although far from being an enlightened monarch, Joseph II understood that allowing Jews to serve in the military might be of financial benefit to his Empire. This started through his series of Toleranzpatente in the last two decades of the eighteenth century. This liberalization continued, with ups and some downs, until the beginning of World War I, with Jews promoted to high rank and even ennobled. By contrast, in Prussia, only one Jew, Meno Burg, was promoted to officer's rank: Jews were not allowed to become reserve officers; Germany entered the war without a single Jewish commissioned officer. The relatively benign rule of Emperor Franz Joseph-who saw no reason to discriminate against "his" Jews-succeeded in retaining rights for Habsburg Jews, in and out of the military, despite prevalent bourgeois antisemitism.

Understanding of the role played by Jews in the Habsburg Empire requires knowledge of the history of Hungary, in particular the Kossuth Rebellion of 1848 and the Ausgleich (compromise) of 1867. Jews played a significant role 
in the Kossuth Rebellion, and were, for a short time, punished for their activities. The rebellion raised their Magyar sentiment and, when the Ausgleich occurred, they entered the military in large numbers. They assimilated (or tried to), Magyarized their names, and mixed marriages were common. By contrast, Orthodox Galician Jews initially attempted to escape military service by buying themselves out or leaving the area. This gradually ceased, but Orthodoxy remained.

When contrasted with the two countries against which the Central Powers would fight on the Eastern Front and in the Alps during the war, Italy was the most liberal in its treatment of Jews. After the risorgimento, Jews were granted full rights, and progressed through the general staff to ministerial status without problem. Every effort was made during the war to comply with religious laws, and Italy had the highest per capita number of serving Jews of all warring parties. By contrast, Tsarist Russia oppressed its Jews with pogroms and the Pale of Settlement; there were no Jewish chaplains, and Jews were not promoted to officer's rank. Despite this, Russian Jews volunteered enthusiastically in large numbers when war began.

Identifying the primary culprit who caused World War I has occupied historians for decades. Austro-Hungary entered the war with the mistaken idea that they could deal with the Serbs in a short, sharp, limited war. The AustroHungarian army was not properly modernized, and its leaders, personified by Conrad von Hötzendorf, lacked insight and modern thinking of their German counterparts. It could be said that Habsburg generals were fighting the previous war, and it became rapidly clear to the German Army that they were "shackled to a corpse." Nevertheless, there was no lack of bravery in the AustroHungarian army, only bad and disorganized leadership, which the men recognized quickly and complained about vociferously. The ease with which troops on the Eastern Front gave up and went into imprisonment had multiple causes other than cowardice. On the Italian Front, Austrians fought with determination and bravery, on perhaps the worst front in the war.

Definitive statistics are not available, but between sixteen and thirty-one percent of Austro-Hungarian soldiers were taken captive, and spent prolonged periods of time in prisoner of war camps all over Russia and Central Asia. In Central Asia, Austro-Hungarian Jews came into contact for the first time with Bukharan communities, in distant towns and cities of which they had previously never heard. A large number of Jewish civilians from Przemyśl and other occupied cities were caught up in the prisoner-of-war net, and shared the same fate as captured soldiers. Jewish prisoners of war often found civilians in nearby 
towns who tried to be of assistance. Descriptions of Bukharan synagogue services and a Pesach seder in Turkestan are unique. The master of the house, who has two wives, is astonished when told that polygamy is not permitted amongst Ashkenazi Jews. Kaspar Blond describes an escape odyssey through Persia and Mesopotamia, and reports effects of the Armenian genocide in Aleppo.

As with my previous two books, my desire in the current volume was to give voices to long-dead men: expressing their feelings, desires, and impressions of the war. In recent years, historians have reanalyzed and rethought the contents of World War I diaries and memoirs, modifying and sometimes changing the original narrative. This has not been my aim. My belief is that thoughts and concepts of a conflict such as World War I must be analyzed with insights of the times during which they were written. Exaggerated patriotism may seem ridiculous today with a century's hindsight but at the time feelings were real and cogent.

The more than twenty nationalities of the polyglot Habsburg Empire, each with their own culture and traditions, complicated military communication, making language an important issue in troop coordination. Jewish soldiers' knowledge of languages, including German and Yiddish, gave them important places as translators and liaison with local civilian Ostjuden. Austro-Hungarian soldiers came into contact with Ostjuden on a long-term basis; Christians and the majority of Jews in the army regarded them as a curiosity, something outside their normal purview. Influx of expelled Ostjuden refugees into large cities such as Vienna did not improve their acceptance in the community.

Whereas the less than fifty German Jewish chaplains left sufficient written material (monographs, festival and other sermons) to fill more than one book, their Austro-Hungarian counterparts yielded scant archival material, and I was left with newspaper articles and letters to describe the feelings and activities of more than 130 chaplains from all over the Empire. A picture emerges of chaplains who were perhaps less secularly learned than their German counterparts, but whose chief interest lay in action, not writing. In contrast to their more liberal German counterparts, Austro-Hungarian chaplains dealt with Orthodox Jewish soldiers from Galicia and Bukowina, who were much more interested in mutual expounding of a page of Torah or Talmud than food, cigarettes, or newspapers. In this regard, the newspaper articles of Rabbi Leo Bertisch are instructive. The fifty-six-year-old Rabbi Adolf Kelémen is also unique, because he died from wounds received on the front. I could find no other Jewish chaplain of the Central Powers who died in the field. 
The diary of Bernhard Bardach, published recently in my English translation for the first time, reports almost each day of the war in minute detail. It includes people, places, offensives (with a detailed description of the Brusilov Offensive), personal family details, description of Ostjuden, and of mounting food shortages as the war progressed. It also includes photographs from his unique collection of over 900 photographs. Teofil Reiss, from a large Lemberg family with relatively little education, participates wherever needed as cook, food-gatherer, and medical orderly. He has at least one young lady (sometimes more than one) in almost every town he visits. His description of one of these ladies, who arrived at the camp and announced herself as his wife, is comical. Dolu Rawitz's diary from the Italian front is full of scathing criticisms of bad leadership.

The two Hebrew novels by Avigdor Hameiri-a Hungarian from Carpatho-Ruthenia-about his participation in World War I are unique. Hameiri volunteered as soon as the war began, and served on the Carpathian and Eastern Fronts from the beginning of the war until he was taken prisoner during the Brusilov Offensive in June 1916. Both books are excerpted in this volume. The first book, The Great Madness, includes a wide cast of characters from all over the Habsburg Empire: Galician and Hungarian Jews (converted, assimilated, and Orthodox), Austrians, Croats, Poles, Ruthenians, Czechs, even a Gypsy or two. His reports, spiced with his acerbic humor, are mostly historically correct but he sometimes lapses into "autofiction."

Hameiri's second book, Hell on Earth, which was recently published for the first time in my English translation, deals with Hameiri's imprisonment in camps all over European Russia, Siberia, and Turkestan during 1916-1917. He is accompanied by three faithful friends: a faithful Calvinist Magyar, a yeshiva student with an agile sense of humor, and a humble Gypsy. All three die en route, the first two in gruesome ways. Some of the material is historically accurate, but some is presented as "auto-fiction" amidst a great deal of seeming hallucination due to extreme suffering. The book also includes a description of Russian Jewry suffering under Tsarist oppression, the geography of the entire area, historical personalities of all types, and camp life and its attendant corrupting influences. Hameiri was liberated in spring 1918 and spent the time until his immigration to Palestine in 1921 in Ukraine. There, he witnessed the Ukrainian anti-Jewish pogrom of 1918-1920. Like the journalist John Reed, he was there to observe everything.

The palette of Jews in the Austro-Hungarian Army is so wide that no one single book can hope to do it justice. It is my hope that this book will stimulate 
other researchers - with a broader command of languages than myself-to complement and broaden my findings.

This book could not have been written without the cooperation of a great many people from many countries who provided advice, information on books and memoirs, and archival assistance. Frank Mecklenburg, Michael Simonson, and Tracey Felder (Leo Baeck Institute, New York), Inka Arroyo Altezana and her staff (Central Archives for the History of the Jewish People, Jerusalem), Irene Aue Ben David (Leo Baeck Institute, Jerusalem), Lia Toaff and Sylvia Haia Antonucci (Archivio Storico della Comunità Ebraica di Roma), Christoph Tepperberg and his staff (Österreichisches Staatsarchiv/ Kriegsarchiv, Vienna), Tomáš Krákora (Czech Jewish Museum, Prague). Translation and other valuable advice and assistance was given by Ljiljana Dobrovšak and Mihaela Peric (Croatian), PierLuigi Briganti (Italian), Rudolf Kučera, Kateřina Kuklíková, Pavla Urbaśkova, Katariná Pomorska (Czech), Jan Rybak, Konrad Zielinski, Marek Gałęzowski, Maciej Gorny, Michał Czajka, Stanislava Caravoulias (Polish), Yochanan Petrovsky Shtern (Russian). I thank Manfried Rauchsteiner for continued support, manuscript critique, and gracing the book with a foreword. Similarly, I thank Gerald Lamprecht for his scholarly introduction and the photograph of the Jewish Soldiers' Memorial in Vienna. Jay Winter, Marc Saperstein, and Georg Wurzer critiqued various parts of the manuscript and offered valuable suggestions. A special thanks to Georg Wurzer for sharing unique references on the Austro-Hungarian prisoner-of-war experience, obtaining (with permission) and translating documents from the State Archives of the Russian Federation, Moscow into German, and assistance with Sütterlin transcriptions. I thank Paul Bihari for sharing his doctoral dissertation with me. Ernst Schmidl, Marcus Patka, and Martin Senekowitsch are thanked for valuable advice, and Annette Hübner for transcribing cursive German. I thank Glenda Abramson for help with works by Uri Zvi Greenberg.

The following are thanked for copyright approval of archives and photographs: Leo Baeck Institutes in New York and Jerusalem; Austrian National Library; Vienna War Archives; Archiv der Republik; Jewish Museum, Vienna; Central Archives of the History of the Jewish People, Jerusalem; Museum of Czech Literature and Prague Jewish Museum, Prague; Altona Museum, Goldberg Collection; Jewish Historical Museum, Amsterdam; the Jewish Historical Archives in Rome; Katya Krausova; Buchhandlung Stöhr Verlag; Foto Fayer \& Co. I thank Eva Buchberger (Böhlau Verlag) for permission to cite material from E. A. Schmidl, Habsburgs jüdische Soldaten; Ktav Publishing for permission to cite J. Schoenfeld, Shtetl Memoirs; Tuvia Erez for permission 
to translate and excerpt portions of his grandfather Teofil Reiss's diary; Yoni Shapira and his brothers for giving me permission to publish my own and other translations of works by their grandfather; Jonathan Orr Stav and Ilana Hairston for permission to paraphrase portions of their mother Yael Lotan's translation of Hameiri's The Great Madness; Tim Demy and Joseph Phillips (Stone Tower Books and Black Widow Press) for permission to cite excerpts of my recent edited version of The Great Madness; Wayne State University Press for permission to cite sections of my translation of Hameiri's Hell on Earth; the Random House Group for permission to quote From Chronicle of a Life by S. Trebitsch, published by William Heinemann; Cahill, Gordon, and Reindl LLP for permission to cite excerpted material by Hans Kohn. I thank Alessandra Anzani, Matthew Charlton, Ekaterina Yanduganova, Kira Nemirovsky, Ilya Nikolaev, and the staff at Academic Studies Press for their kind cooperation. Esther Dell and Robin Long provided invaluable library assistance, and Eleanor Leo took care of all things software.

The first shall come last: I thank my dearest wife Addie (eishet chayil mi yimtza) for her Job-like patience and forbearance during many years of travail and doubts, carefully reading through the entire manuscript, and providing valuable insights. This book would not have been possible without her. I thank my daughter Madeleine for a daughter's love.

Any errors in facts or presentation are all mine.

Peter C. Appelbaum

Land O Lakes, FL

August 2020 